\title{
Reflection on the Computer and Network-based College English Teaching Model From the Perspective of Learning Styles
}

\author{
Yaping Zhou \\ Foreign Languages School, Zhejiang Ocean University \\ 18 Haiyuan Road, Dinghai District, Zhoushan City, Zhejiang Province, 316000, China \\ Tel: 86-580-818-0286 E-mail: zyp@zjou.edu.cn
}

Received: June 15, 2011

Accepted: July 17, 2011

Published: October 1, 2011

doi:10.5430/wjel.v1n2p30

URL: http://dx.doi.org/10.5430/wjel.v1n2p30

The research is financed by Scientific Research Fund of Zhejiang Provincial Education Department (No. 20070326) and the Educational Reform Project of Zhejiang Ocean University (No. 11072892409).

\begin{abstract}
College English is a compulsory course in Chinese higher education curriculum. Under the guide of College English Curriculum Requirements in 2004, many universities have undertaken the experiment of computer and network-based teaching model which is supposed to provide individualized learning for students of different kinds and improve the effect of college English teaching and learning. In order to learn the effects of this new teaching model, an investigation was carried out among the students who had taken part in the teaching experiment in Zhejiang Ocean University. The results show that $67 \%$ of the students are in favor of the new teaching model. More extroverted students like the new model than the introverts. The new model seems to fit better to those students who are active in study and who prefer independent learning. To produce the expected results of the new teaching model, teachers should take students' different learning styles into consideration.
\end{abstract}

Keywords: Computer and network-based teaching model, Learning styles, College English

\section{Introduction}

College English is an obligatory course for non-English major undergraduate students in China. It is a systematic and independent subject and also one of the most important components of the Chinese higher education curriculum. College students are required to take two-year English classes and pass corresponding achievement tests to earn credits needed for a degree. In 2004, the Higher Education Bureau of the Ministry of Education of China issued the new College English Curriculum Requirements, which opened the reform of College English teaching in China. In the requirements, it is stressed that learning should be individualized and teaching should be tailored to the unique attributes of every student. The requirements also require that all universities and colleges widely apply advanced information technology to language teaching and learning and promote computer and network-based English teaching and learning in order to provide the students with a superior language learning environment. After that, many universities and colleges in China began to build the network language lab to apply this new teaching medium to the daily English language teaching and learning. Computer and network-based language teaching is a kind of teaching model based on computer hardware techniques, multimedia techniques, Internet and the software of the multimedia courseware. Therefore, this teaching model is completely different from the traditional one. Quite a few research and studies have been done on this new teaching model since then (He and Zhong, 2007; Zhang, 2006; Zhou and Zhuan, 2009). However, there is little research on the relationship between this new teaching model and the students' learning styles. In this article the following questions are addressed:

What's the students' attitude towards the new teaching model?

What kind of students like this kind of teaching model?

How can the new teaching model cater to students' individualized learning styles? 


\section{College English Teaching Reform in China}

College English is a compulsory course, but the teaching methods used by the college English teachers are very traditional and quite out of date. In the traditional teaching method, the teacher takes up most of the class time teaching linguistic knowledge while the students listen passively and take notes on whatever the teacher says. Students seldom have opportunities for the actual use of English. Under this kind of teaching and learning, students will lose learning incentives, activeness, self-reflection, and creativity.

However, with the entry of China into WTO and the expansion of the higher education in China, more and more problems arise in College English teaching and learning. Students are becoming dissatisfied with the teaching and learning process because they find they still can't communicate effectively even though they have passed CET4 or CET6. Teachers find it more and more difficult to conduct their teaching as students' English levels are more diverse and their needs and learning styles are more individualized because of the expansion of the class size. It is very apparent and urgent for College English teaching to reform.

In this case, the new College English Curriculum Requirements were issued in 2004 to serve as the guideline for the College English transformation in China. The primary objective of the reform is to develop students' ability to communicate in English through listening, speaking, reading, and writing. Special attention is also given to independent learning and the cultivation of individual personalities.

In order to achieve this objective, the requirements proposed a new College English teaching model, that is, the computer-plus-classroom teaching model. In the classroom teaching, teachers give instruction on grammar, reading, writing, and translating skills along with learning strategies, and also provide opportunities for discussion, question-and-answer sessions, and individual guidance. In the network computer lab, students carry out the computer-assisted learning individually according to the given courseware because the computer-assisted learning can cater to individual needs through active, independent study.

It is expected that the combination of the traditional face-to-face classroom teaching with the computer-assisted learning can provide an effective mechanism for English learning. It is also hoped that this new teaching model can be of help in improving the skills of English learners, even in promoting their self-study in and out of the classroom.

\section{The Teaching Experiment in Zhejiang Ocean University}

With the Requirements serving as an outline for College English reform, many universities and colleges conducted experiments to teach College English with new teaching models that capitalize on advanced information technology. As one of the universities in China, we were also very interested in the new teaching model. After we visited the 4 universities, which were the first pilot universities in Zhejiang assigned by the Ministry of Education, we tried to follow these examples and did a pilot teaching experiment. In September 2005, we chose 6 classes in Grade 2005 to have the new computer and network-based teaching model. Under this new teaching model, the students had two periods of lectures in the multimedia classroom mainly for intensive reading, two periods of students' learning in the network computer lab mainly for listening and speaking with the instruction of the teachers and another two periods for students to do self-study in the computer lab. Both the students and the teachers who conducted the experiment were satisfied with this kind of teaching model. Therefore, based on the experiment, we chose 11 classes in Grade 2006 to have this computer and network-based teaching model beginning from September 2006 for four semesters. The students had 2 periods in the classroom and 2 periods in the network computer lab under the instruction of the teachers, and another 2 periods for self-learning in the computer lab. We used the textbook New College English compiled by Zhejiang University and published by Foreign Language and Research Press. While in the network computer lab, we provided the textbook's network courseware for students' autonomous learning. The courseware provided the students with a platform for their self-study at their own pace. Teachers could supervise their study online. In the computer lab, students could preview and review the contents in the textbooks, practice listening and speaking, do homework assigned by the teachers, and choose some other materials that fit their interests and needs to assist their learning.

As we know, the computer and network-based teaching model is different from the traditional teaching model in many aspects. The greatest differences lie in the teaching method and the roles of both the teacher and the students. In the new teaching model, the teaching method is the combination of the teacher instruction and the student autonomous learning with teachers having multi roles as organizers, facilitators and helpers and students changing from passive learners into active and autonomous learners. The new teaching model is a real challenge for the teachers and the students as well. In order to learn more about the effects of the new teaching model, we conducted an investigation among the students who had taken part in the teaching experiment for three semesters in March 2008. 


\subsection{Subjects}

The subjects for this study were 157 non-English majors in grade 2006 of Zhejiang Ocean University. They came from different majors such as electronic information engineering, civil engineering, mechanical designing and automation, history, Chinese language, mathematics and applied mathematics, marine science, tourism management and so on. They were chosen at random by their English teachers from the 11 experimental classes with an average of 15 students in each class. Among them, there were 96 male students and 61 female students.

\subsection{Methods and data collection}

The teaching experiment lasted from September 2006 to June 2008 for four semesters. The investigation was conducted in March 2008 when the experiment was in the beginning of the fourth semester. In order to learn the result of the new teaching model, we developed a questionnaire that consisted of two parts. Part 1 is about the subjects' background information, such as name, class, major, sex and score on CET-4. Part 2 was made up of four sections. Section A is about the general opinion or attitude toward the new teaching model. Section B is about the students' learning beliefs. Section $\mathrm{C}$ is about the students' learning strategy use. Section D is about the students' learning styles. Each section has five to six multiple-choice questions or open questions. These questions were printed on a piece of paper and students were asked to write down their answers according to their own experience and opinion. The questionnaires were given to the students chosen by their English teachers. The students did the questionnaires in their spare time and handed in to their English teachers when they came to the class next time. The questions were all in Chinese so that students could express their opinions clearly. After we got the questionnaires, we analyzed the qualitative data by organizing, summarizing and synthesizing. In this paper, only the results of Section A and Section D were analyzed and presented.

\subsection{Results}

\subsubsection{Students' attitude toward the new teaching model}

In Section A, we have a question which intends to learn about the students' general opinion about the new teaching model. We ask students to tell whether they like the new teaching model or not by choosing one of the choices given on the questionnaire. Table 1 show that 105 students say that they definitely like the new teaching model, which accounts for $67 \%$ of the subjects. Only 12 students say that they don't like it. From this, we can see that the majority of students have positive attitudes to it, which means that this new model is popular with university students.

$<$ Table 1 about here $>$

\subsubsection{About the personality and the new teaching model}

One of the factors that can affect a learner's learning styles is the personality. Personality factors significantly influence the degree of success that individuals achieve in learning a second language (Gass \& Selinker, 1994). It has been shown that personality traits such as extroversion, assertiveness, emotional stability, adventurousness, and conscientiousness have significant relationships with successful language learning (Reiss, 1981). Oxford and Nyikos (1989) have realized that successful language learners choose strategies to go well with their personalities. In order to learn whether the new teaching model has something to do with the learners' personality, we have developed a question in Section D. This question asks students to tell what kind of personality they have by choosing among the three given options. Among the 157 students, only 24 students choose "extroverted" and 30 students choose "introverted", while the rest (103) choose "both". To have a close look at the relationship between the personality and the new teaching model, we divide the students into three groups according to their perceived personality and calculate the students who like the new teaching model in each group. 19 students out of the 24 extroverts like the new teaching model, which takes up 79 percent, while only 18 out of the 30 introverts like the new model, which is only $60 \%$. From this, we can see that more extroverts like the new teaching model.

\subsubsection{About the learning styles and the new teaching model}

In Section D, Question 3 and Question 4 are developed to analyze whether this new teaching model suits students of different learning styles. Question 3 is a multiple-choice question to learn about students' perceived learning styles. Students may choose more than one options among the six given options based on their own learning experiences and opinions. The result is presented in Table 2.

\section{$<$ Table 2 about here $>$}

Question 4 is an open question, which asks the students to tell whether this new teaching model fit their learning styles or not and why.

To learn more about the relation between learning styles and this new teaching model. We have calculated the number of 
students in each category. Among 157 students, 82 students say definitely that this kind of teaching model fits their learning styles and 37 students say that this model almost fit their learning styles. However, there are still 31 students who think that this model doesn't fit them.

In the category of "Passive" learning style, only 5 students say that this model fit them, which takes up about $15 \%$. In the category of "Cooperative" learning style, only 13 students think that the model fit them, which is about $43 \%$. However, more than $60 \%$ percent say that the model fit them in the rest four categories.

$<$ Table 3 about here $>$

From the results, we can see that the new teaching model fit more than half of the students, but it may cater better to students preferring active and independent learning styles than to those who are passive in learning and who prefer cooperative learning style. This model doesn't cause too much difference to the students who are auditory or visual.

\section{The Advantages of the Computer and Network-based Teaching Model}

The results of the teaching experiment and the investigation tell us that the majority of the students who took part in the experiment approve of the new computer and network-based teaching model in College English.

To know better about the effect of the new teaching model, we have analyzed the reasons given by the students in the questionnaires. From the students' answers, we learn that students like this new teaching model because the new teaching model has the following advantages.

First, it can give students more freedom and learning flexibility. As teaching materials are available whenever and wherever they want, students can start at their own learning level, set their own schedule, go at their own pace and learn what they want to learn. Most students enjoy setting their own paces, making informed choices about their needs according to their ability and being able to develop skills of self-assessment.

Second, it can activate students' autonomous learning. Just as one of the subjects said, it can make them study actively and autonomously because they can study independently and do the exercises by themselves. The new model makes great positive effects on enhancing autonomous learning environment and further provides an optimal environment for the development of learner autonomy (Wu, 2009).

Third, it realizes individualized teaching and learning. It provides students with one-to-one learning situation. Students, especially those with lower English levels, can have all the time they need to think out their ideas, ask questions and give answers in private without the fear of ridicule from others. What one student in our investigation replied is a good case in point. This student considers himself as a passive learner, but he says that this model fits him quite well because he will not feel nervous when he is studying alone facing the computer instead of the teacher and classmates.

As we know, it is very difficult for teachers to keep all the learners actively engaged in the learning process and learning at the same pace (Wrigley and Guth, 1992). This new teaching model can help the teachers solve this problem to some extent. With computers and networks, students can learn at a comfortable pace and interact directly and continually with computers that provide immediate feedback. In this kind of teaching and learning, students can learn either online or using specially designed software without the limitations of time, place, and learning style. This new teaching model can, to a certain degree, meet the needs for individualized instruction because it has infinite resources of patience and can teach on a one-to-one basis at a pace dictated by the individual's capabilities.

\section{Implications for the Future Teaching}

However, the investigation also shows that there are still 31 students who think that the new model doesn't fit them. These students are mostly passive in learning and have a preference of cooperative learning style. Some students say that this model gives them no pressure. Others say that they are used to the traditional way of teaching in high schools. Still others say that this kind of teaching and learning is too boring because there is no interaction and discussion. From these comments, we can see that the computer and network-based teaching model is not suitable to every student and it has to be improved to meet the needs of different students.

In order to carry out the computer and network-based teaching model effectively, we should take the following suggestions into consideration from the perspective of students' learning styles.

\subsection{Incorporating the instruction of learning styles to help students become independent learners}

From the study, we can see that the computer and network-based teaching fit better for the students who are active and independent in learning. Students who are passive and don't like English still find the model not fit for them because it can't arouse their interest in learning English. To make these students accept the new teaching model, teachers should first try to change the students from their traditional role of passive learners into the new role of active and autonomous 
learners. To successfully change students into active and independent learners, teachers can incorporate the teaching of learning styles as a part of teaching content because some knowledge of one's own learning style is essential in "learning to learn" (Smith and Associates, 1990). Teachers should help students discover their own learning preferences and provide constructive feedback about the advantages and disadvantages of various styles. Also, teachers should respect the students' present preferences and encourage their development, while at the same time creating opportunities for students to experiment with different ways of learning. When the students know their learning style, they will integrate it in the process of learning so they will learn more easily, faster and will be more successful (Biggs, 2001). The success in learning will, in turn, enforce students' motivation and confidence, and gradually lead students into active and independent learners.

As we know, a learner's learning style includes not only the cognitive domain, but also the affective and physiological domains (Oxford et al., 1992). In order to make the new teaching model fit to as most students as possible, teachers should make students aware of the processes involved in language learning and the system of the new teaching model. Teachers can help students adapt to the new teaching and learning environment by analyzing the students' learning style preferences, teaching them how to help themselves and how to manage their own learning. Teachers can regularly collect and analyze data on student knowledge, interests, and aptitude provided by the software in the new model. The software in computer and network-based teaching equips teachers with the information necessary to predict students' learning capacities and provide additional opportunities to help students develop to their full potential. If teachers can combine students' cognitive elements with their affective ones in the new teaching model, they will succeed in enhancing student knowledge and skills simultaneously, as well as in developing student interests, motivation and confidence. Only when the students see the styles of teaching fit their individual learning style and experience the success of learning will they change their perspectives on learning new things and finally approve of the new teaching model.

\subsection{Providing ample opportunities for social interaction to fit students of cooperative learning preference}

As we know, the need for social interaction and communication is ultimately necessary in learning a second or foreign language. However, the computer and network-based teaching is based on computer-assisted individual learning and it separates learners from each other and for the most part from the teacher. As a result, students who prefer cooperative learning will suffer from a lack of social interaction and communication. To solve this problem, teachers should enhance face-to-face classroom teaching by carefully selecting teaching content and designing mini-projects for students to accomplish in class. They should also create ample opportunities for students to interact with each other or with the teacher on the Internet and after classes. By combining different kinds of social interactions into the computer-assisted individual learning, the new teaching model will meet the needs of both extrovert learners and introvert learners, as well as the needs of students who prefer cooperative learning.

\subsection{Exercising effective management and supervision to help those who are passive and lack of self-control in their learning}

The computer and network-based teaching model have the advantages over the traditional teaching methods in many aspects. However, if teachers don't take effective measures to supervise students' learning, the new teaching model will amount to little effect. In the computer and network-based teaching model, students who are more likely to have problems are those who cannot easily concentrate, cannot stay with a task until it is completed, do not pay attention to details, have poor memories for facts, and have poor reading skills (Ross and Schulz, 1999). During the process of online learning, students cannot be completely supervised and controlled by teachers. Those who are used to the strict management of the teachers may chat online, watch movies, play computer games or do whatever they like. They will take advantage of the individualized learning time in the computer lab to do things that has nothing to do with their English study. In addition, as there are so many resources in the computer lab some students will feel at a loss what to choose because they don't know what is suitable for them and how to do if they are not familiar with the computer knowledge. As a result, they will develop a negative attitude to the teaching model because it brings them too much trouble. Therefore, teachers should not just give instructions in the new teaching model, but learn to manage and supervise students' online learning. Teachers should set rules for students' learning in the computer lab in the beginning of the course. Teachers should also check and examine students' assignments and quizzes often and give feedback and comments as soon as possible. If teachers can take effective measures to manage and supervise students' learning, the new teaching model will produce better results.

\section{Conclusion}

The computer and network-based teaching model is introduced into College English teaching in China with the assumption that this model could meet the needs of different learners and improve the efficiency of English teaching and 
learning. However, students learning college English vary not only in terms of their purposes for learning English, but also in terms of individual differences in learning due to their English level, interest, personality and learning style diversities. There are still a certain number of students who can't adapt themselves to the new teaching model and learning environment (He and Zhong, 2007). We can't take it for granted that the new teaching model can fit every student and produce the effect as expected. To make the new model of college English teaching successful, teachers must understand and respect individuals' diverse learning styles and plan lessons to match students' learning styles while students should try their best to change the traditional beliefs about English learning and learn to diversify their learning style preferences to fit the new teaching model. Only when the teaching approaches match the learning styles of the students can the computer and network-based teaching be applied smoothly and produce the assumed effects.

\section{References}

Biggs, J. (2001). Enhancing learning: A matter of style or approach? In R.J. Sternberg \& L.F. Zhang (eds.), Perspectives on Thinking, Learning and Cognitive Styles. Mahwah, NJ: Lawrence Erlbaum Associates, 73-102.

Gass, S.M.\& Selinker, L. (1994). Second Language Acquisition: An Introductory Course. Hillsdale, NJ: Lawrence Erlbaum.

He, Guoda \& Zhong, Zhiying. (2007). Adaptive study of multimedia-assisted College English teaching. Foreign Language World (2): 9-17.

Oxford, R., Hollaway, M. \& Horton-Murrillo, D. (1992). Language learning style and strategies in the multicultural tertiary L2 classroom. System 20(3): 439-456. http://dx.doi.org/10.1016/0346-251X(92)90057-A

Oxford, R. \& Nyikos, M. (1989). Variables affecting choice of language learning strategies by university students. The Modern Language Journal 73(3), 291-300. http://dx.doi.org/10.2307/327003

Reiss, M.A. (1981). Helping the Unsuccessful Language Learner. The Modern Language Journal 65(2): 121-128. http://dx.doi.org/10.2307/325589

Ross, J. \& Schulz, R. (1999). Can computer-aided instruction accommodate all learners equally? British Journal of Educational Technology 30(1): 5-24. http://dx.doi.org/10.1111/1467-8535.00087

Smith, R.M. and Associates. (1990). Learning to Learn across the Life Span. San Francisco, CA: Jossey-Bass, Inc., Publishers.

Wrigley, H.S.\& Guth, G.J.A. (1992). Bringing Literacy to Life: Issues and Options in Adult ESL Literacy. San Mateo, CA: Aguirre International.

Wu, Shao-yue. (2009). A study of network-based multimedia college English autonomous teaching and learning model. US-China Foreign Language 7(7): 38-55.

Zhang, F. (2006). Using multimedia and network technology to reform College English teaching in the teaching of New Horizon College English. CELEA Journal 29(3): 111-114.

Zhou, Yaping \& Zhuan, Biyun. (2009). On the Effects of Network-based Teaching Model on Students Language Learning Beliefs. Journal of Zhejiang Ocean University (Humane Science) 26(3): 80-83. 
Table 1: Students' attitudes toward the new teaching model

\begin{tabular}{|l|c|c|c|c|}
\hline \multirow{3}{*}{ Do you like the new teaching model? } & Yes, very much & Just so-so & No, not at all & No answer \\
\cline { 2 - 5 } & 105 & 35 & 12 & 5 \\
\cline { 2 - 5 } & $67 \%$ & $22 \%$ & $8 \%$ & $3 \%$ \\
\hline
\end{tabular}

Table 2: Students' choices on the learning styles

\begin{tabular}{|c|c|c|c|c|c|}
\hline Passive & Active & Independent & Cooperative & Auditory & Visual \\
\hline 33 & 31 & 87 & 30 & 34 & 47 \\
\hline
\end{tabular}

Table 3: Learning styles and the new teaching model

\begin{tabular}{|l|c|c|c|c|}
\hline \multirow{2}{*}{ Does the new model fit your learning styles? } & Fit & Almost fit & Not fit & No answer \\
\cline { 2 - 5 } & & & & \\
\hline Passive & $82(52 \%)$ & 37 & 31 & 7 \\
\hline Active & $5(15 \%)$ & 13 & 15 & $/$ \\
\hline Independent & $20(65 \%)$ & 5 & 6 & $/$ \\
\hline Cooperative & $54(62 \%)$ & 21 & 12 & $/$ \\
\hline Auditory & $13(43 \%)$ & 8 & 9 & $/$ \\
\hline Visual & $24(70 \%)$ & 4 & 6 & $/$ \\
\hline
\end{tabular}

